\title{
Molecular characterization and phylogenetic analysis of coat protein gene of Leek yellow stripe virus infecting garlic in India
}

\author{
NITIKA GUPTA ${ }^{1,2}$, R.K. JAIN ${ }^{1}$, G.P. RAO ${ }^{1}$ and VIRENDRA KUMAR BARANWAL ${ }^{1 *}$ \\ ${ }^{1}$ Plant Virology Unit, Division of Plant Pathology, ICAR-Indian Agricultural Research Institute, New Delhi 110012 , India \\ ${ }^{2}$ Present Address: ICAR-Directorate of Floricultural Research, College of Agriculture Campus, Shivajinagar, Pune 411005 , \\ Maharashtra, India
}

Received: 14 December 2016/ Accepted: 8 February 2017/ Published online: 23 March 217

(C) Indian Phytopathological Society 2017

\begin{abstract}
The coat protein (CP) gene of two isolates of Leek yellow stripe virus (LYSV) from India was sequenced and found to be $864 \mathrm{bp}$, encoding a protein with 288 amino acids. The CP sequences of both the isolates were deposited in GenBank with accession numbers KF724857 and KP168262 corresponding to the isolates AC-50 and PGS-14, respectively. The Indian isolates of LYSV shared maximum nucleotide (nt) and amino acid (aa) identities of $85 \%$ and $90 \%$ respectively with that of Myanmar isolate (AB551622). Nt and aa based sequence identities of two Indian LYSV isolates with the corresponding sequences of 34 other LYSV isolates from worldwide revealed that, Indian isolate shared $77-84 \%$ and $80-90 \%$ identity respectively among themselves. It showed $5.3 \%$ diversity between the Indian isolates and $23 \%$ diversity among the isolates reported worldwide. Amino acid sequence comparison showed high variability at N-terminal region of CP gene of LYSV. Phylogenetic analysis of CP sequences of 36 isolates comprising India and other isolates from world segregated them into two major groups (major group I and major group II). The Indian isolates were clustered with isolates of Myanmar (AB551622) and Japan (AB194640) in subgroup III of major group II. The phylogenetic analysis revealed that Indian isolate is closely related to an isolate from Myanmar (AB551622). The present study comprises the first report on unravelling the molecular variability existing among the LYSV isolates.
\end{abstract}

Keywords: Coat protein, Leek yellow stripe virus, phylogenetic analysis, sequence analysis, variability

Garlic (Allium sativum L.) is one of the most important culinary spice crops of the world. It is widely used as antibiotic, anti-cancerous, anti-diabetic, anti-oxidant and poses lipid lowering properties (Keusgen, 2002). Garlic is a sulfur-containing edible plant which contains several active compounds including alliin, allicin, S-allyl-cysteine, S-methyl-cysteine and several other bio-active molecules in varying concentrations. These compounds occuring in garlic supplements are responsible for the health effects (Upadhyay, 2016). Garlic has been used for centuries for medicinal benefits such as promoting heart health, reducing cholesterol and triglycerides; it inhibits platelet aggregation (thins blood) and lowers blood pressure (Kuesgen, 2002). On the other hand, it is carminative and gastric stimulant thus aiding in digestion and absorption of food.

Production and productivity of garlic is limited by several abiotic and biotic factors, especially viral diseases which are responsible for decreasing yield and diminishing bulb and clove quality. Since agamic propagation of garlic is preferred due to its sexual sterility, garlic plants in the field are naturally infected with mixture of plant viruses. In India, six viruses belonging to four

${ }^{*}$ Corresponding author: vbaranwal2001@yahoo.com different taxonomic groups namely, Allexivirus (Garlic virus $X$; Garv-X), Potyvirus (Onion yellow dwarf virus; OYDV and Leek yellow stripe virus; LYSV), Carlavirus (Garlic common latent virus; GarCLV and Shallot latent virus; SLV), Tospovirus (Iris yellow spot virus; IYSV) has been reported to infect garlic (Ghosh and Ahlawat, 1997; Majumder and Baranwal, 2009; Gawande et al., 2010; Baranwal et al., 2011; Gupta et al., 2013). Mixed viral infection results in mosaic pattern, chlorotic streaking, mottling, twisting with curling of leaves and stunting of plants, leading to the formation of small bulbs and cloves, and reduction in the yield to the tune of $78 \%$ with respect to bulb weight (Lot et al., 1998; Conci et al., 2003; Lunello et al., 2007). Potyviruses are responsible for the major economic loss in garlic globally, causing severe bulb weight reduction (Lunello et al., 2007; Bagi et al., 2012).

Leek yellow stripe virus (LYSV) is a member of the genus Potyvirus, belonging to the family Potyviridae. LYSV has flexuous, filamentous particles of $815-820 \times$ $11-13 \mathrm{~nm}$, harbouring a single molecule of linear ssRNA of approximately $10.2 \mathrm{~kb}$ (Bos et al., 1978; Davis, 2008). LYSV is considered as the most important virus infecting garlic due to its wide distribution and severe symptom production (Van Dijk, 1993; Van Dijk et al., 1994). The infected plants exhibit mosaic and yellow stripe 
symptoms on leaves and may produce smaller, malformed bulbs resulting in severe yield reduction and poor quality which varies depending on the cultivars (Lot, 1998; Takaki et al., 2005). LYSV is transmitted by aphids and may easily re-infect virus-free garlic plants in the fields (Yoshida et al., 2012). LYSV infects garlic, leek (Allium porum) and other Allium species and represents a virus of great economic importance. A number of reports have described the incidence and epidemiology of LYSV in Greece (Dovas et al., 2001), Italy (Dovas and Volvas, 2003), Brazil (Fajardo et al., 2001), Argentina (Conci et al., 2002), Japan (Takaichi et al., 2001) the USA (Pappu et al., 2005) and India (Gupta et al., 2013).

In the present study, garlic plants exhibiting light yellow striping on the leaves and stunting symptoms were collected from the field of ICAR-IARI, New Delhi and were tested for the presence of LYSV using different diagnostic protocols. The coat protein gene of the LYSV was characterized to determine genetic variability and phylogenetic relationships among the LYSV species.

\section{MATERIALS AND METHODS}

\section{Collection of isolates}

The bulbs of twenty one garlic accessions were collected from the field of Division of Vegetable Science, ICARIARI, New Delhi, India and tested for the presence of LYSV through double antibody sandwich enzyme linked immunosorbent assay (DAS-ELISA) using polyclonal antiserum against LYSV (Bioreba, Switzerland) (Gupta et al., 2013). Based on the ELISA positive reaction for LYSV, two isolates of LYSV were selected: AC-50 and PGS-14. Leaves from tissue cultured, virus-free garlic plants produced at Division of Plant Pathology, ICARIARI, New Delhi were used as healthy control.

\section{RNA isolation and RT-PCR}

Primer LYSVCP-F (GCTGGTGAGGAGATTGATG) and primer LYSVCP-R (CTGCATATGCGCACCATC) were designed and synthesized at Sigma Aldrich Co. India for amplification of 864 bp LYSV CP gene. Total RNA was isolated using the RNeasy Plant Mini Kit (QIAGEN GmbH, Hilden, Germany) as per manufacturer's instructions. RNA was first reverse transcribed into cDNA. The total $20 \mu \mathrm{l}$ reverse transcription PCR mixture containing $0.2 \mu \mathrm{M}$ reverse primer (LYSVCP-R), 5U MuLVRT (MBI, Fermentas, Inc., Hanover, MD, USA), 2 $\mu \mathrm{l}$ of $5 \mathrm{X}$ reaction buffer and $0.3 \mathrm{mM}$ dNTPs was incubated at $42^{\circ} \mathrm{C}$ for 45 minutes. The resultant/synthesized cDNA served as templates for subsequent PCR amplification using primers specific to the CP of LYSV. The PCR reaction mixture of $50 \mu \mathrm{l}$ contained $10 \mu \mathrm{l}$ of cDNA, $2 \mu \mathrm{l}$ of $10 \mathrm{mM}$ dNTPs, $2.5 \mathrm{mM} \mathrm{MgCl}_{2}, 2 \mu \mathrm{l}$ each of forward and reverse primers $(100 \mathrm{pmol} / \mu \mathrm{l}), 5 \mu \mathrm{l}$ of $10 \mathrm{X}$ PCR reaction buffer, 5U Taq polymerase (MBI, Fermentas, Inc., Hanover, MD, USA) and autoclaved double distilled water to make up the volume. The thermo cyclic programme was: hot start at $94^{\circ} \mathrm{C}$ for $5 \mathrm{~min}$, denaturation at $94^{\circ} \mathrm{C}$ for $30 \mathrm{sec}$, annealing at $58^{\circ} \mathrm{C}$ for $45 \mathrm{sec}$ and extension at $72^{\circ} \mathrm{C}$ for $1 \mathrm{~min}$. After 35 cycles the final extension was performed at $72^{\circ} \mathrm{C}$ for $10 \mathrm{~min}$. All the amplifications were carried out in Mastercycler Gradient (Eppendorf, USA). The amplified products were analyzed by agarose gel electrophoresis and stained bands were visualized using an UV-transilluminator (Biorad, USA).

\section{Cloning, sequencing and sequence analysis}

The purified PCR products corresponding to the CP gene of two LYSV isolates (AC-50 and PGS-14) were cloned into pGEMT-Easy vector (Promega, Madison, USA) using T4 DNA ligase (supplied with cloning kit). Two positive clones for each isolate were selected by standard colony PCR (Sambrook et al., 2001) with CP specific primers as well as, by restriction digestion of purified plasmid with EcoRI. Selected clones were sequenced using the vector derived primers T7 and SP6 using an AB 13130 Genetic analyzer (Chromous Biotech, Bangalore, India and Xcelris, Ahmadabad, India). The consensus sequences were aligned through multiple alignments with Clustal X version 2 (Larkin et al., 2007). The sequences of the two Indian LYSV isolates along with other LYSV CP sequences retrieved from GenBank data base were used for sequence comparisons. Percent identity was calculated for the full CP of the different LYSV isolates using the BioEdit sequence alignment editor version 7.1.3 (Hall, 1999). Neighbour Joining phylogenetic tree was constructed using the program MEGA6 (Tamura et al., 2013). The evolutionary distances were computed using the p-distance method with 1000 bootstrap replications. To identify variable and conserved region in the $\mathrm{CP}$, the protein variability server (http://imed.med.ucm.es/PVS/) was used. To determine the conserved domains in the CP sequence, online protein analysis tools such as SMART (Letunic et al., 2009) and MEME (Bailey et al., 2006) were used.

\section{RESULTS}

\section{Cloning, sequencing and sequence analysis}

An amplicon of 864 bp corresponding to the complete CP gene of LYSV was amplified using primer pair

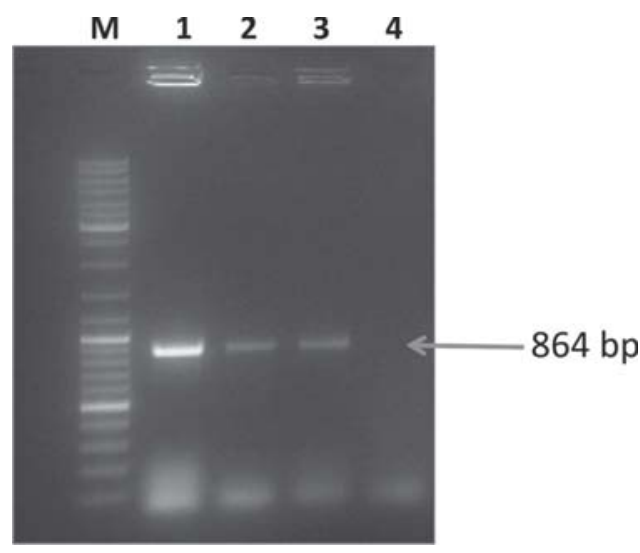

Fig. 1. Agarose gel electrophoresis showing specific RT-PCR amplification of full coat protein (CP) gene of Leek yellow stripe virus (LYSV) isolates. Lane M: 100 bp DNA ladder; lane 1 (LYSV positive sample), lane 2 \& 3 (cultivar PGS14 \& AC-50), lane 4 (LYSV negative sample) 
LYSVCP-F and LYSVCP-R for the two isolates viz. AC50 and PGS-14 (Fig. 1). Complete coat protein sequence obtained for the two isolates were confirmed through basic local alignment searching tool (BLAST) and consensus $\mathrm{CP}$ sequences of the two isolates were deposited in GenBank under accession numbers KF724857 and KP168262 corresponding to AC-50 and PGS-14, respectively. In Indian isolates, length of the $\mathrm{CP}$ was found to be 864 nucleotides (288 amino acids) which shared nucleotide identity of $94.7 \%$ between them. In nucleotide BLAST, CP gene of Indian isolate showed maximum identity of $85 \%$ with Myanmar isolate (AB551622) with 100\% query coverage. Comparison of 36 LYSV CP sequences (including isolates in the present study) from different parts of the world, revealed $77-84 \%$ and $80-90 \%$ identity in nucleotide and amino acid regions, respectively among themselves (Table 1). When CP gene of 36 LYSV isolates from India and other isolates from the world was compared, it showed $5.3 \%$ diversity between Indian isolates with an overall diversity up to $23 \%$ among different isolates worldwide (Table 1).

Multiple alignment of $36 \mathrm{CP}$ amino acid sequences revealed that, most of the variability was located within the $\mathrm{N}$-terminal 50 amino acids (Fig. 2 \& 3). The C-terminal region was highly conserved in all the isolates of LYSV. This data was also supported by the protein variability plot generated through protein variability server at a variability threshold of 1.0 (http://imed.med.ucm.es/PVS/) (graph not shown). Protein variability server (http:// imed.med.ucm.es/PVS/) detected the occurrence of a single conserved fragment ( $\geq 6$ amino acids) with no variable residues (under the variability threshold of 1.0) in the CP gene of 36 LYSV isolates, which is located between 20-26 amino acid (D K S I E Q R) position from $\mathrm{N}$-terminal to C-terminal. Pfam search predicted the presence of one conserved domain in LYSV CP which belonged to the protein family PF00767 (Pfam: Poty_coat from 52-286). This protease is found in genome polyproteins of potyviruses. SMART search also revealed the presence of other different conserved domains like Beta-trefoil DNA-binding domain (3-138), FERM Cterminal $\mathrm{PH}$-like domain (40-112), BAF - Barrier to autointegration factor, act as a DNA-bridging protein (71143), elF5A- Eukaryotic elongation factor 5A hypusine, DNA-binding OB fold (148-204).

Three motifs were predicted by MEME online program. Motif 1 had following signature sequences, VNVGTTGTFSVPRIKQI[PS]QKGI[SA]IPMDGGKSILNL DHLLQY KP[NS]QL[NC]ISN with aa position from 54103 while, motif 2 had following signature sequences LMVWCIENGTSPNING[TV]WTMMDG[DE]EQV[EA] [YF]PLRP[IV]VEHA [KQ]PTLRQIMAHFS as signature sequence aa position from 136-185 and motif 3 had

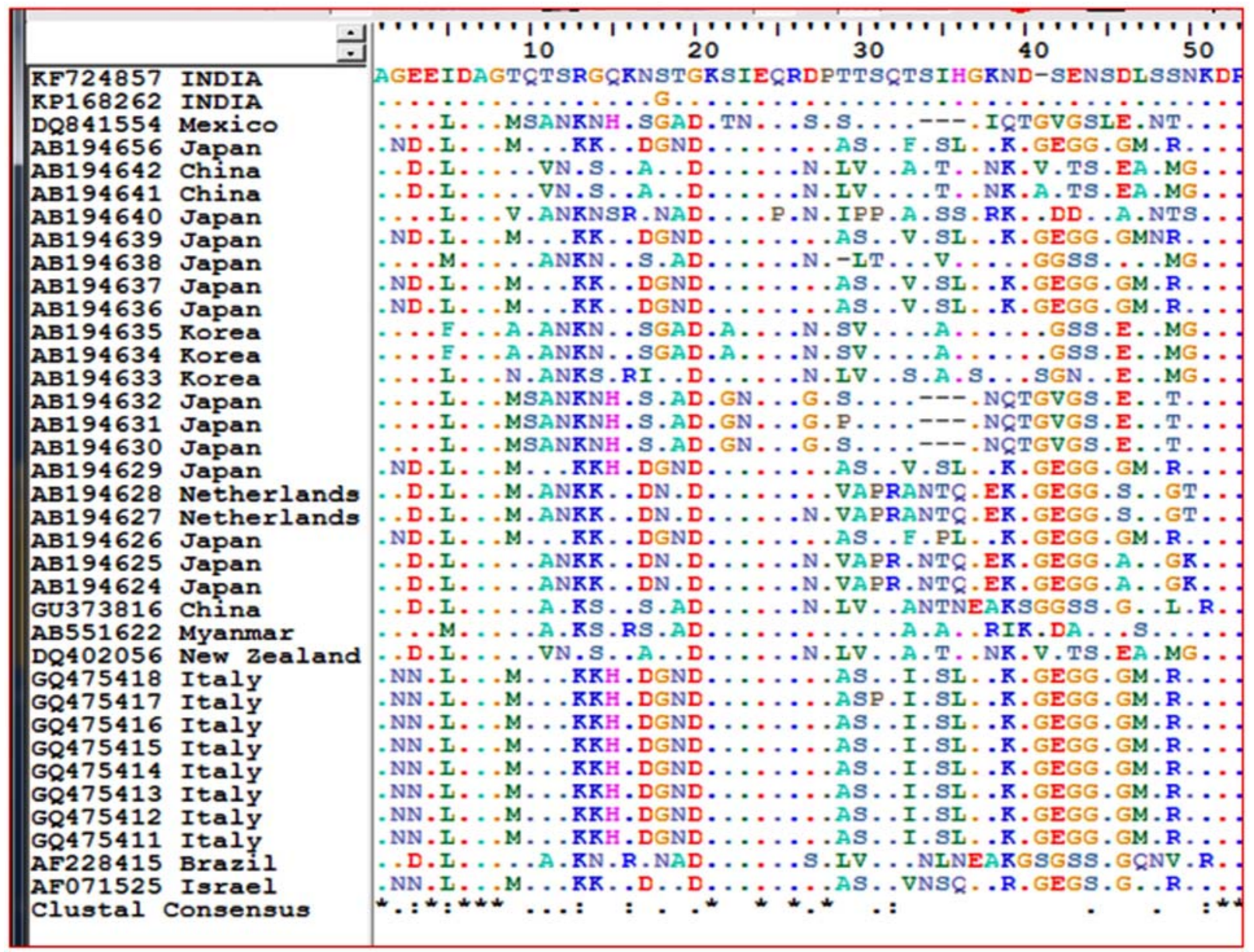

Fig. 2. Multiple alignment of coat protein (CP) of 36 Leek yellow stripe virus (LYSV) isolates from diverse geographical origin showing variability in amino acid sequences at the $\mathrm{N}$-terminal of $\mathrm{CP}$ 


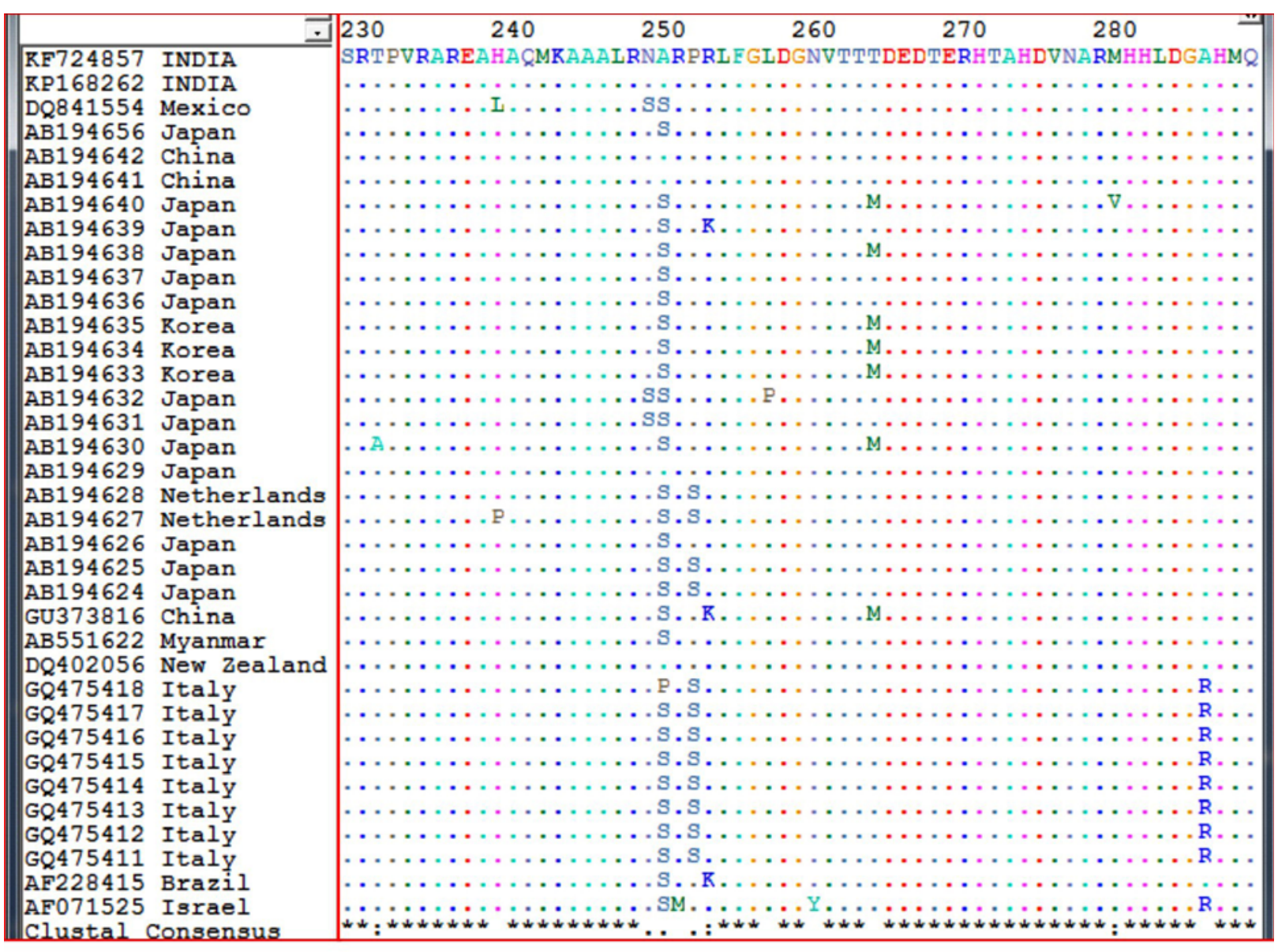

Fig. 3. Multiple alignment of coat protein (CP) of 36 Leek yellow stripe virus (LYSV) isolates from diverse geographical origin showing less variability in amino acid sequences at the C-terminal of $\mathrm{CP}$

Table 1. Sequence identity (\%) of coat protein (CP) gene of Leek yellow stripe virus isolates

\begin{tabular}{lccc}
\hline $\begin{array}{l}\text { Accession number } \\
\text { in GenBank }\end{array}$ & Country & $\begin{array}{c}\text { Nucleotide } \\
\text { identity (\%) }\end{array}$ & $\begin{array}{c}\text { Amino acid } \\
\text { identity (\%) }\end{array}$ \\
\hline KF724857 & India & $77.2-94.7$ & $80.2-98.6$ \\
KP168262 & India & $77.9-94.7$ & $80.6-98.6$ \\
DQ841554 & Mexico & $77-96.9$ & $80.2-96.8$ \\
AB194656 & Japan & $78-99.8$ & $81.6-99.6$ \\
AB194642 & China & $77-99.5$ & $80.9-99.6$ \\
AB194641 & China & $77.5-98.6$ & $80.6-98.6$ \\
AB194640 & Japan & $77-81.3$ & $79.9-85.7$ \\
AB194639 & Japan & $77.8-98.1$ & $80.2-98.6$ \\
AB194638 & Japan & $76.5-87.5$ & $79.9-93$ \\
AB194637 & Japan & $77.8-98.6$ & $81.3-99.3$ \\
AB194636 & Japan & $77.9-99.3$ & $81.6-99.3$ \\
AB194635 & Korea & $77.6-99.6$ & $80.6-93$ \\
AB194634 & Korea & $77.5-99.6$ & $80.6-93$ \\
AB194633 & Korea & $77.9-85.9$ & $79.9-90$ \\
AB194632 & Japan & $77.3-99$ & $80.2-98.2$ \\
AB194631 & Japan & $78-99$ & $80.2-98.2$ \\
AB194630 & Japan & $79-93$ & $80.9-95.8$ \\
AB194629 & Japan & $77.2-95.6$ & $80.6-98.9$ \\
AB194628 & Netherlands & $78.5-99.6$ & $79.9-98.9$ \\
AB194627 & Netherlands & $78.4-99.6$ & $79.5-98.9$ \\
\hline
\end{tabular}

\begin{tabular}{lccc}
\hline AB194626 & Japan & $78-99.1$ & $81.6-99.6$ \\
AB194625 & Japan & $78.6-99.7$ & $79.5-99.6$ \\
AB194624 & Japan & $78.6-99.7$ & $79.9-99.6$ \\
GU373816 & China & $78.8-88.5$ & $83.3-93.4$ \\
AB551622 & Myanmar & $76.8-84.9$ & $79.5-90.6$ \\
DQ402056 & New Zealand & $77.8-99.5$ & $81.3-99.6$ \\
GQ475418 & Italy & $76.6-99.8$ & $79.9-99.6$ \\
GQ475417 & Italy & $76.7-99.8$ & $79.9-99.6$ \\
GQ475416 & Italy & $76.5-99.6$ & $79.9-99.3$ \\
GQ475415 & Italy & $76.7-100$ & $80.2-100$ \\
GQ475414 & Italy & $76.7-100$ & $80.2-100$ \\
GQ475413 & Italy & $76.7-100$ & $80.2-100$ \\
GQ475412 & Italy & $76.5-99.7$ & $80.2-100$ \\
GQ475411 & Italy & $76.6-99.8$ & $79.9-99.6$ \\
AF228415 & Brazil & $78-88.5$ & $81.6-93.4$ \\
AF071525 & Israel & $77.4-93.7$ & $79.9-95.5$ \\
\hline
\end{tabular}

signature sequences, YIEMRN[SA]EQAYMPRYGLQRN LTDM[GS]LARYAFDFYEVTSR TPVRAREAHAQ with aa position from 191-240 in CP of all the isolates of LYSV.

Phylogenetic analysis of CP sequences of 36 isolates containing Indian and other isolates of LYSV from world separated them into two major groups (major group I and major group II). Major group I was further divided 


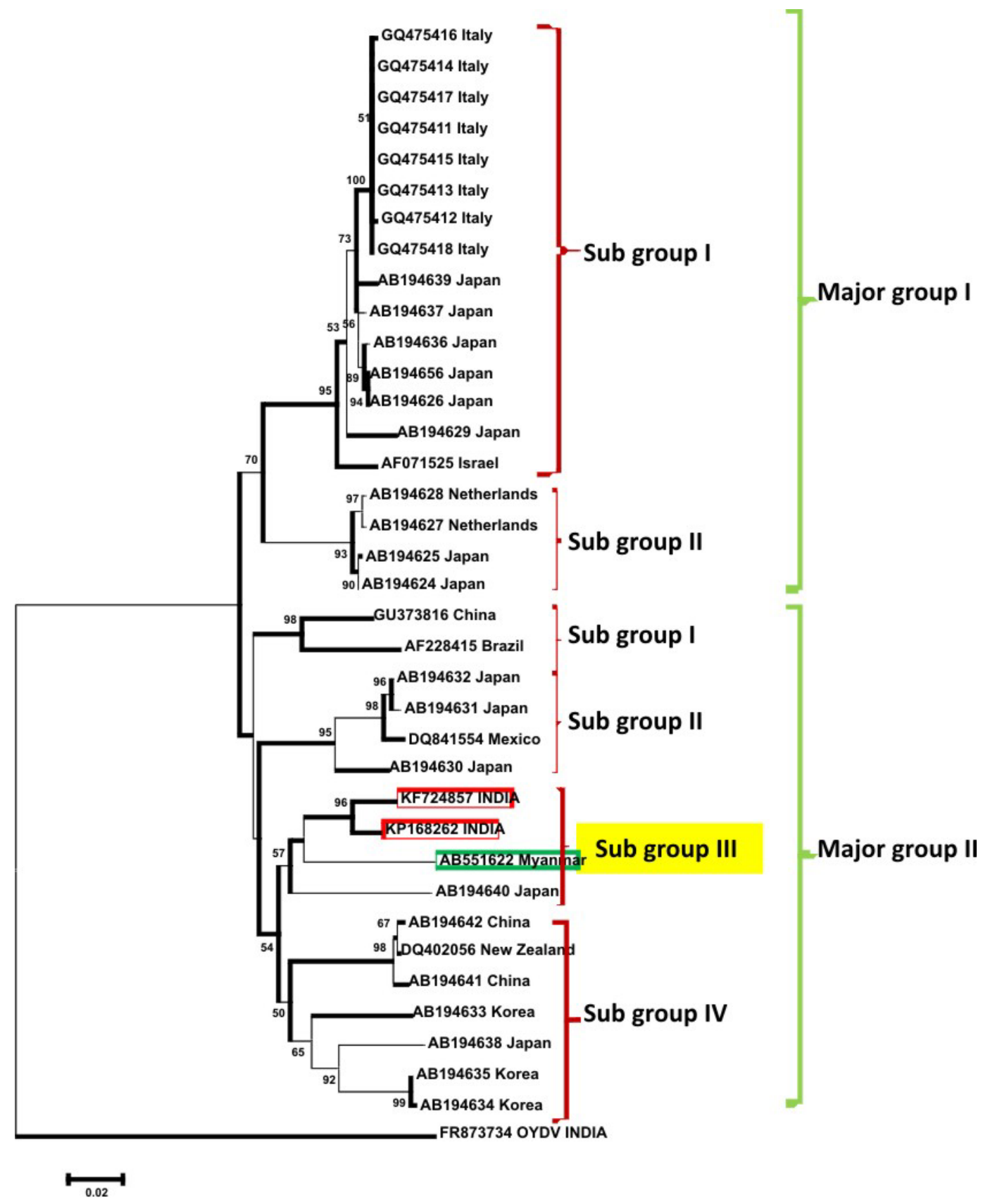

Fig. 4. Phylogenetic analysis of coat protein (CP) of LYSV infecting Allium species. The evolutionary history was inferred using the Neighbor-Joining method. The bootstrap consensus tree inferred from 1000 replicates is taken to represent the evolutionary history of the taxa analyzed. Branches corresponding to partitions reproduced in less than 50/bootstrap replicates are collapsed. The percentage of replicate trees in which the associated taxa clustered together in the bootstrap test (1000 replicates) are shown next to the branches. The evolutionary distances were computed using the p-distance method and are in the units of the number of base differences per site. Evolutionary analyses were conducted in MEGA6. OYDV was taken as an out group

into two sub groups (sub group I and II) and major group II was separated into 4 sub groups (sub group I, II, III, IV). LYSV isolates from leek were clustered into subgroup II of major group I and the length of CP was $267 \mathrm{nt}$. Indian isolates were clustered with isolates of Myanmar (AB551622) and Japan (AB194640) into subgroup III of major group II and the length of CP was 864. The CP gene of OYDV (FR873734) was used as an out-group. This phylogenetic analysis revealed that, Indian isolates of LYSV is closely related to LYSV isolates representing Myanmar and Japan (Fig. 4).

\section{DISCUSSION}

The identification and characterization of viruses infecting garlic are based on serology, host range and sequence data of coat protein (Kobayashi et al., 1996; Tsuneyoshi et al., 1998; Fajardo et al., 2001). Recent advancements in molecular biology have provided a new paradigm for the classification and identification of viruses. Molecular characteristics such as the viral genome sequences, coat protein (CP) sequences and genome organizations are useful for distinguishing virus species, strains and 
determining the relationships between genera, species and subspecies of distinct viruses. Genome sequence based detection and characterization have been employed successfully for garlic viruses such as OYDV, LYSV, SLV, GarCLV and allexiviruses. It has been very useful in classification, their definite detection and differentiation from other species within the same genus infecting garlic (Tsuneyoshi et al., 1998; Takaichi et al., 1998; Fajardo et al., 2001, Chen et al., 2001; Dovas et al., 2001; Adams et al., 2005).

Amongst all the genes of the potyviral genome, the coat protein $(\mathrm{CP})$ is the most frequently selected for studies of genetic diversity. The 3'-terminal position of the $\mathrm{CP}$ in the viral genome has contributed to the availability of a large number of $\mathrm{CP}$ sequences for different potyviruses and comparison of $\mathrm{CP}$ aa sequences has allowed discrimination between species and strains (Shukla and Ward, 1988; Adams et al., 2005; Desselberger et al., 2009). An updated comparison of $\mathrm{CP}$ sequences has led to assign members of the family Potyviridae into genera, distinct species, related species, and strains (Ward and Shukla et al., 1994; Adams et al., 2005).

As functions of only a small fraction of known proteins have been determined experimentally, the use of computational sequence analysis has become essential for the annotation of novel genes and prediction of protein structure and function. Many proteins are multidomains in characters and possess multiple functions that are often performed by one or more component domains (Schultz et al., 1998). Similarly, CPs of the RNA viruses are remarkably multifunctional proteins and hence made up of many domains and motifs (domains collection that performs wide spectrum function) (Tatineni et al., 2011; Vaira et al., 2012). In the present study, different protein analyses tools were used to detect the conserved domains within the CP of LYSV, which plays structural and functional role like Beta-trefoil DNA-binding domain, FERM C-terminal PH-like domain, BAF - Barrier to autointegration factor, act as a DNA-bridging protein and elF5A- Eukaryotic elongation factor 5A hypusine, DNA-binding etc. This study revealed that, the CP is not only having structural role but also has regulatory function. Annotation of molecular function in sequence database is difficult to interpret giving that the term function may describe phenomenon occurring at distinct levels, such as those of amino acids, domains, proteins, molecular complexes, cells, organs, organism, etc. Nevertheless, the annotated domains and motifs are the first step to begin with and can provide useful hints toward experimental characterization of function at different levels. Although, we could predict the existence of different motifs and domains in the $\mathrm{CP}$, further functional studies will throw a light on their role on virus survival, transmission, synergism with other co-infecting viruses and induction of disease.

When CP gene of LYSV isolates, including two Indian isolates compared, LYSV Indian isolates shared maximum nt and aa sequence identity with the Myanmar isolate (AB551622) and also exhibited 5.3\% diversity between Indian isolates with an overall diversity up to $23 \%$ among different isolates worldwide. Amino acid sequence of the coat protein, especially the N-terminal region, has been proved to be useful in Potyvirus taxonomy (Shukla et al., 1988; Riechmann et al., 1992). Multiple alignment of aa sequence data clearly showed that, the N-terminal of CP of LYSV is highly variable which has also been substantiated by Wei et al. (2006).

In general, high sequence variability among different LYSV isolates is well documented (Fajardo et al., 2001; Chen et al., 2002). A comparison of nucleotide and/or amino acid sequences of CP has led to the partition of LYSV isolates into two phylogenetic groups (Chen et al., 2002; Tsuneyoshi et al., 1998). Takaki et al. (2005) proposed a distinct (third) group for the isolates from Northern Japan that are closely related to LYSV isolates from leek. Our findings presented here could represent independent evolution of geographically distant virus isolates and/or selection pressure; implying adaptation of the virus (Fajardo et al., 2001). Based on phylogenetic analysis, the group I included 17 garlic and 2 leek LYSV isolates originating from Italy, Japan, Netherlands and Israel. These isolates showed nucleotide and amino acid identities of $76.5-100 \%$ and $79.9-100 \%$, respectively. The group II comprised 17 garlic LYSV isolates originating from China, Japan, Brazil, Myanmar, Korea, New Zealand, Mexico and India. These isolates exhibited similar identities, i.e., $77-99.6 \%$ for nucleotides and 79.9 $99.6 \%$ for amino acids.

Overall, phylogenetic studies revealed that, Indian isolates of LYSV clustered along with the isolates from Myanmar and Japan in subgroup III of major group II. Phylogenetic studies showed that, geographical origin and evolutionary process of the garlic viruses could not be correlated. Several investigators have reported that, vegetative propagation of garlic over several generations and easy exchange of biological propagation materials between countries might have resulted in high variability and rapid evolution of garlic viruses (Koo et al., 2002). The genetic variability is also probably due to the frequent mixed infection occurring in the same garlic plant that favours interactions between different genotypes of the same species or closely related species.

In conclusion, complete nucleotide sequencing of LYSV isolates reported till today along with several isolates representing other garlic growing regions of the world can shed more light on the understanding of diversity and evolution of LYSV. The broad distribution and occurrence of garlic viruses reinforce the need of a garlic-seed certification programme in India, which is essential to improve the health conditions of the crop. Thus, the use of virus-free propagation material is strongly recommended and it is essential that commercial crops be completely separated from propagation crops in order to avoid contamination.

\section{ACKNOWLEDGEMENTS}

First author is grateful to Department of Science and Technology for INSPIRE fellowship during Ph.D. 
programme. The funding from ICAR network and outreach project is gratefully acknowledged. The help rendered by Dr. Sabina Islam, Scientist, Division of Vegetable Science, IARI, New Delhi in providing garlic accessions is highly acknowledged. The Authors are also thankful to The Head, Division of Plant Pathology and The Director, ICAR-Indian Agricultural Research Institute, for necessary lab facilities.

\section{REFERENCES}

Adams MJ, Antoniw JF and Fauquet CM (2005). Molecular criteria for genus and species discrimination within the family Potyviridae. Arch. Virol. 150: 459-479.

Bagi F, Stojsin V, Budakov D, El Swaeh SMA and GvozdanovicVarga J (2012). Effect of onion yellow dwarf virus (OYDV) on yield components of fall garlic (Allium sativum L.) in Serbia. Afr. J. Agric. Res. 7: 2386-2390.

Bailey TL, Williams N, Misleh C and Li WW (2006). MEME: Discovering and analyzing DNA and protein sequence motifs. Nucleic Acids Res. 34: W369-W373 (Web server issue).

Baranwal VK, Singh P and Jain RK (2011). First report of Garlic virus $X$ infecting garlic in India. Plant Dis. 95: 1197.

Bos L, Huijberts N, Huttinga H and Maat DZ (1978). Leek yellow stripe virus and its relationships to Onion yellow dwarf virus - characterization, ecology and possible control. Nether. J. PI. Patho. 84: 185-204.

Chen J, Chen JP and Adams MJ (2001). Molecular Characterisation of a complex mixture of viruses in garlic with mosaic symptoms in China. Arch. Virol. 146: 18411853.

Chen J, Chen JP and Adams MJ (2002). Characterisation of some carlaand potyviruses from bulb crops in China. Arch. Virol. 147: 419-428.

Conci VC, Canavelli A and Lunello P (2003). Yield losses associated with virus-infected garlic plants during five successive years. Plant Dis. 87: 1411-1415.

Conci VC, Lunello P, Buraschi D, Italia R and Nome SF (2002). Variations of Leek yellow stripe virus concentration in garlic and its incidence in Argentina. Plant Dis. 86: 1085-1088.

Davis RM (2008). Garlic Mosaic. Compendium of Onion and Garlic Diseases and Pests. H.F. Schwartz and M.K.S. St. Paul, Amer Phytopatholo Society.

Desselberger U and Ball LA (2009). Virus taxonomy. VIIIth report of the international committee on taxonomy of viruses. Elsevier/ Academic Press 819-829.

Dovas C I, Hatziloukas E, Salomon R, Barg E, Shiboleth Y and Katis NI (2001). Incidence of viruses infecting Allium spp. in Greece. Eur. J. Plant Pathol. 107: 677-684.

Dovas $\mathrm{Cl}$ and Vovlas C (2003). Viruses infecting Allium spp. in Southern Italy. J. Plant Pathol. 85: 135.

Fajardo TVM, Nishijima M, Buso JA, Torres AC, Ávila AC and Resende RO (2001). Garlic viral complex: Identification of Potyviruses and Carlavirus in central Brazil. Fitopatol. Bras. 26: 619-626.

Gawande SJ, Khar A and Lawande KE (2010). First report of Iris yellow spot virus on garlic in India. Plant Dis. 94: 1066.

Ghosh DK and Ahlawat YS (1997). Filamentous viruses associated with the mosaic disease of garlic in India. Indian Phytopath. 50: 266-267.

Gupta N, Prabha K, Islam S and Baranwal VK (2013). First report of Leek yellow stripe virus in India from garlic. J. Plant Pathol. 95: 69-77.
Hall TA (1999). BioEdit: A user-friendly biological sequence alignment editor and analysis program for Windows 95/ 98/NT. Nuc. Aci. Sympos. Ser. 41: 95-98.

Keusgen M (2002) Health and Alliums. In: Rabinowitch HD, Currah L (Eds.) Allium Crop Science: Recent Advances. Wallingford, UK, CABI Publishing, pp. 357-378.

Kobayashi K, Rabinowicz P, Bravo-Almonacid F, Helguera M, Conci V, Lot H and Mentaberry A (1996). Coat protein gene sequences of garlic and onion isolates of the onion yellow dwarf potyvirus (OYDV). Arch. Virol. 141: 2277-2287.

Koo BJ, Kang SG and Chang MU (2002). Survey of garlic virus disease and phylogenetic characterization of garlic viruses of the genus Allexivirus isolated in Korea. Plant Pathol. J. 18: $237-243$

Larkin MA, Blackshields G, Brown NP, Chenna R, McGettigan PA, McWilliam H, Valentin F, Wallace IM, Wilm A, Lopez R, Thompson JD, Gibson TJ and Higgins DG (2007). Clustal W and Clustal $X$ version 2.0. Bioinformatics. 23: 2947-8.

Letunic I, Doerks T and Bork P (2009). SMART 6: Recent updates and new developments. Nucleic Acids Res. 37: 229-232.

Lot H (1998). Effects of Onion yellow dwarf and Leek yellow stripe viruses on symptomatology and yield loss of three French garlic cultivars. Plant Dis. 82: 1381-1385.

Lunello P, Di Rienzo J and Conci V (2007). Yield loss in garlic caused by Leek yellow stripe virus Argentinean isolate. Plant Dis. 91: 153-158.

Majumder S and Baranwal VK (2009). First report of Garlic common latent virus in Garlic from India. Plant Dis. 93: 106-106.

Pappu HR, Hellier BC and Dugan FM (2005). First report of Onion yellow dwarf virus, Leek yellow stripe virus and Garlic common latent virus in garlic in Washington State. Plant Dis. 89: 205-205.

Riechmann J, Lain S and Garcia J (1992). Highlights and prospects of potyvirus molecular biology. The J. General Virol. 73: 1-16.

Sambrook J and Russell RW (2001). Molecular Cloning: A Laboratory Manual. $3^{\text {rd }}$ Ed. Cold Spring, NY, Cold Spring Harbor Laboratory Press.

Schultz J, Milpetz F, Bork P and Ponting CP (1998). SMART, a Simple Modular Architecture Research Tool: Identification of signalling domains. Proc. Natl. Acad. Sci. USA. 95:58575864 .

Shukla DD and Ward CW (1988). Amino acid sequence homology of coat proteins as a basis for identification and classification of the potyvirus group. J. Gen. Virol. 69: 27032710.

Takaichi M, Nagakubo T and Oeda K (2001). Mixed virus infections of garlic determined by a multivalent polyclonal antiserum and virus effects on disease symptoms. Plant Dis. 85: 71-75.

Takaichi M, Yamamoto M, Nagakubo T and Oeda K (1998). Four garlic viruses identified by reverse transcriptionpolymerase chain reaction and their regional distribution in northern Japan. Plant Dis. 82: 694-698.

Takaki F, Sano T, Yamashyta K, Fujita T, Ueda K and Kato T (2005). Complete nucleotide sequences of attenuated and severe isolates of Leek yellow stripe virus from garlic in northern Japan: Identification of three distinct virus types in garlic and leek world-wide. Arch. Virol. 150: 1135-1149.

Tamura K, Stecher G, Peterson D, Filipski A and Kumar S (2013). MEGA6: Molecular Evolutionary Genetics Analysis Version 6.0. Mol Biol and Evol. 30: 2725-2729. 
Tatineni S, Van Winkle DH and French R (2011). The N-terminal region of Wheat streak mosaic virus coat protein is a hostand strain-specific long-distance transport factor. J. Virol. doi:10.1128/JVI.02044-10.

Tsuneyoshi T, Matsumi T, Natsuaki KT and Sumi S (1998). Nucleotide sequence analysis of virus isolates indicates the presence of three potyvirus species in Allium plants. Arch. Virol. 143: 97-113.

Upadhyay RK (2016). Garlic: A potential source of pharmaceuticals and pesticides: A review. Intern. J. Green Phar. 10: 1-27.

Vaira AM, Lim H, Bauchan GR, Owens RA, Natilla A, Dienelt MM, Reinsel MD and Hammond J (2012). Lolium latent virus (Alphaflexiviridae) coat proteins: Expression and functions in infected plant tissue. J. Gen. Virol. 93: 18141824.
Van Dijk P (1993). Survey and characterization of potyviruses and their strains of Allium species. Nether. J. Plant. Pathol. 99: 1-48.

Van Dijk P and Van der Vlugt RAA (1994). New mite-borne virus isolates from rakkyo, shallot and wild leek species. Europ. J. Plant. Pathol. 100: 269-277.

Ward CW and Shukla DD (1994). Structure and variation of potyviruses. In Virol. in the Tropics. 43-61. (Eds.) by Rishi N, Ahuja KL, Singh BP New Delhi: Malhotra Publishing House.

Wei T, Pearson MN and Fletcher JD (2006). Molecular confirmation of New Zealand garlic yellow streak virus as Leek yellow stripe virus. Aus. Plant Path. 35: 341-346.

Yoshida N, Shimura H, Yamashita K, Suzuki M and Masuta C (2012). Variability in the P1 gene helps to refine phylogenetic relationships among Leek yellow stripe virus isolates from garlic. Arch. Virol. 157: 147-153. 